UDC 323.1:316.3: $316.42(477)$

DOI: $10.33402 / \mathrm{nd} .2020-8-134-149$

\title{
Orest KRASIVSKYI
}

Doctor of Historical Sciences, Professor

Head of the Department of European Integration and Law at the Lviv Regional Institute of Public Administration of the National Academy of Public Administration under

the President of Ukraine

ORCID: https://orcid.org/0000-0002-7028-6038

e-mail:krasivski@ukr.net

\section{Vasyl PASICHNYK}

Doctor of Science in Public Administration, Associate Professor, Associate Professor at the Department of European Integration and Law at the Lviv Regional Institute of Public Administration of the National Academy of Public Administration under

the President of Ukraine ORCID: https://orcid.org/0000-0002-2447-2374

e-mail:v_pasychnyk@point.lviv.ua

\section{DYNAMICS OF NATIONAL IDENTITY FORMATION IN INDEPENDENT UKRAINE}

The dynamics of national identity formation in independent Ukraine has been studied. Based on the analysis of the results of sociological research, the state, problems, and prospects of Ukrainian national identity formation have been revealed. At the time of the declaration of independence, Ukraine was characterized by a blurred national identity, where regional identities predominated when the West of Ukraine focused on the European Union, and its East and South parts focused on Russia. The sociological research results revealed positive dynamics in the formation of Ukrainian national identity in the conditions of independent Ukraine, as it is a civic identity that has become a priority for the citizens of Ukraine over other group identities. At the same time, the shortcomings of the liberal approach to the formation of national identity, which emphasizes human rights, ignoring the problems of blurred Ukrainian national identity, incomplete nation-building processes in Ukraine, and the collective rights of Ukrainians as the titular nation, are proved. This led to the deepening of divisions and fragmentation of Ukrainian society, the alienation of property and power by the broad masses of people. Russia took advantage of this by unleashing a «hybrid war» against Ukraine and annexing Crimea and part of the Donbas. However, the modern political elite has not drawn proper conclusions, and as the results of recent sociological studies show, it continues to pursue politics, ignoring the Ukrainian national interests and expectations of its own people. The priority of national 
integration and ensuring the national unity of Ukraine has been justified while maintaining the priority of European integration concerning other areas of foreign policy orientation and international integration. It is proved that the conceptual basis for consolidating the people of Ukraine can be primarily the Ukrainian national idea.

Keywords: national identity, Ukraine, consolidation of society, Ukrainian national idea.

Having been part of foreign empires for many centuries and experiencing national oppression from them, the Ukrainian ethnic group began to lose its historical memory, language, culture, traditions, etc. Historically, similarities with a somewhat mixed ethnic composition on the border of Ukraine have been formed, and the Ukrainian population of these regions has been affected by the long-term cultural and political influence of neighboring countries. Therefore, at the time of the declaration of independence, Ukraine was characterized by a blurred national identity, where regional identities prevailed. Today, there is a need to study the dynamics of the formation of national identity in independent Ukraine and determine on this basis the conceptual foundations for the consolidation of Ukrainian society, which today is divided according to regional, ethnic, confessional and social characteristics.

Among the foreign scientific literature on these issues, the works of such scientists deserve special attention: H. Arendt, P. Berger, E. Bubuer, E. Smith, J. Ortega y Gasset, E. Hobsbaum, R. Shporlyuk and others. It is worth noting summarizing researches on these issues of Ukrainian researchers as: V. Maiboroda, Y. Rymarenko, M. Rozumny, M. Stepyko, O. Zabuzhko, M. Ryabchuk, M. Kozlovets, N. Kovtun, O. Rudakevych, M. Marynovych, V. Kremin, V. Tkachenko and others. An important factor in the study of the formation of national identity in independent Ukraine is also the sociological research conducted in independent Ukraine (Razumkov Center, Ilko Kucher Democratic Initiatives Foundation, etc.). .

After the proclamation of independence in Ukraine, national science was dominated by a liberal methodological approach to the formation of a political nation on the basis of citizenship, when the priority was Ukraine's integration into the European Union and implementation of European standards based on human rights. However, at the same time, European integration served as an end in itself, ignoring the problem of blurring of Ukrainian national identity and incompleteness of the nation-building process, as well as the collective rights of Ukrainians as the titular nation and the Crimean Tatar people as an indigenous people in Ukraine. The mindset and expectations of the population of Ukraine in its various regions, as well as the position of the European Union, which did not consider Ukraine as a potential member of the EU even in the long run, were largely ignored. This has led to a deepening of divisions in Ukrainian society, which now highlights the priority of national integration and ensuring the national unity of Ukraine, while maintaining the importance and priority of European integration in other areas of foreign policy orientation and international integration. To justify this scientific approach, we drawn to the results of sociological research conducted after the declaration of an independent Ukrainian state.

The aim of the study is to reveal the dynamics of the formation of national identity in independent Ukraine on the basis of sociological research, identifying the state, problems and prospects of the formation of national identity in modern Ukrainian society.

After the proclamation of independence in the Ukrainian state, a single national identity was not yet formed, as evidenced by the results of sociological researches conducted 
in 1996 by Kyiv sociologists M. Biletskyj and O. Topigo ${ }^{1}$. In Ukraine, first of all, there were two large subregions - «Right Bank» and «Left Bank», which in matters of cultural, economic, party-political and foreign policy spheres took opposite positions. In these sub-regions, two poles are particularly clearly distinguished - Galicia and Donbas, which cultivated in the most «pure» form «Ukrainian» (ethnic) and «Soviet» (conditional name) identities ${ }^{2}$. Galicia understands Ukrainian national identity primarily as an ethno-political community, and Donbass as a community that unites on the basis of citizenship, that is its belonging to the state and a certain territory. Further from these poles to the center of Ukraine, there was a gradual «blurring» of these types of identities, and the formation of certain mixed types with a predominance of features of «Ukrainian» or «Soviet» identity.

These data are also confirmed by the results of a sociological study conducted within the framework of the Genesa Political Science Center in 1997, in which the author also participated $^{3}$. The study showed that in Ukraine, after the declaration of independence, regional identity dominated over national and ethnic identity, which was manifested in various priorities of Ukraine's development. This was shown primarily in the different vision of the regions of Ukraine's future. As well as the lack of consensus on the strategic prospects for the development of the Ukrainian state.

Stagnation and systematic crisis of Ukrainian society has caused dissatisfaction among the population of Ukraine. However, the western and eastern regions of Ukraine saw a different way out of this difficult situation. The population of the East was more inclined to make certain concessions to Russia in matters of state sovereignty, if this generally contributes to improving the financial situation. Western Ukraine does not allow such concessions if they threaten to undermine state sovereignty. They also believe that a higher standard of living can be achieved through integration into the EU and NATO. If the East is focused on integration with Russia, then the West is more inclined to integration with Western Europe. The polar foreign policy orientations of the western and eastern regions generated tension between the Western and The Eastern regions of Ukraine, which appeared primarily in the more critical attitude of the East of Ukraine to its West. In the context of a systemic crisis and low national consolidation of the people, this poses a threat to the national unity and territorial integrity of Ukraine.

Since Ukraine did not pursue a separate state policy in the field of national identity formation and society consolidation, certain interregional contradictions arose and grew in it. These contradictions were especially pronounced during the 2004 and 2010 election campaigns, the Orange Revolution, Euromaidan, and the revolution of dignity, when Ukraine actually shared approximately equal parts of its political preferences: Eastern and Southern Ukraine supported pro-Russian parties, while the West and the Center supported pro-European forces. This was actually taken advantage of by Russia, carrying out information expansion in order to stimulate separatism in the East and South of Ukraine, and later unleashing a «hybrid war» against Ukraine, it annexed Crimea and part of the Donbass (Donetsk and Luhansk regions).

\footnotetext{
${ }^{1}$ Beletskiy M. I., Topygo A. K. National-cultural and ideological orientations of Ukraine. According to sociological polls. Policy. 1998. No. 4. P. 74-89.

2 Ibid. P. 88.

3 Results of the cross-regional sociological survey «the state of Ukrainian society on the eve of the 1998199 elections» conducted by the Genesa Political Science Center under the leadership of Viktor Nebozhenko in May 1997. Stavropigon, 1997. P. 171-193; Pasichnyk V. National security in the context of Ukrainian-Russian relations. Stavropigon. 1997. P. 145-162.
} 
At the same time, the stay of Ukrainian lands in their independent state for a quarter of a century, the Orange Revolution, the Revolution of Dignity and Ukraine's struggle for independence against Russian aggression had a positive effect on the formation of national identity in Ukraine. In particular, this was evidenced by the results of a sociological research conducted by the Razumkov Center in 2016 to study the state and problems of forming the national identity of Ukraine, as well as determine the prospects for consolidating Ukrainian society ${ }^{4}$.

The results of the research by the Razumkov Center in 2016 revealed a certain positive trend in the formation of Ukrainian national identity in the conditions of independent Ukraine, since it is civil and national identity that has acquired priority for Ukrainian citizens in relation to regional, class, religious and political group identities.

Table 1.

Who do you consider yourself in the first place, $\%{ }^{5}$ ?

\begin{tabular}{|l|c|c|c|c|c|c|c|c|}
\hline & Ukraine & West & Center & South & East & Donbass & Ukrainians & Russians \\
\hline A citizen of Ukraine & 58.3 & 62.6 & 63.4 & 63.7 & 52.4 & 45.0 & 61.6 & 33.9 \\
\hline $\begin{array}{l}\text { A resident of the vil- } \\
\text { lage, district or city } \\
\text { in which you live }\end{array}$ & 22.2 & 21.1 & 22.1 & 17.7 & 23.7 & 25.2 & 21.1 & 31.7 \\
\hline $\begin{array}{l}\text { A resident of the } \\
\text { region (district or } \\
\text { districts) where you } \\
\text { live. }\end{array}$ & 11.2 & 9.5 & 8.6 & 12.6 & 14.5 & 14.2 & 10.2 & 18.3 \\
\hline $\begin{array}{l}\text { A citizen of the } \\
\text { world }\end{array}$ & 2.5 & 1.2 & 1.2 & 0.9 & 1.9 & 8.8 & 2.1 & 4.9 \\
\hline $\begin{array}{l}\text { A citizen of the } \\
\text { former USSR }\end{array}$ & 2.3 & 0.2 & 2.0 & 2.3 & 4.8 & 3.1 & 1.4 & 8.5 \\
\hline $\begin{array}{l}\text { A representative of } \\
\text { your ethnic group, } \\
\text { nation }\end{array}$ & 2.0 & 3.8 & 1.5 & 1.4 & 1.9 & 1.3 & 2.1 & 0.9 \\
\hline A citizen of Europe & 0.7 & 0.9 & 0.7 & 0.5 & 0.3 & 1.3 & 0.8 & 0.4 \\
\hline A citizen of Russia & 0.1 & 0.2 & 0.0 & 0.5 & 0.3 & 0.0 & 0.1 & 0.4 \\
\hline
\end{tabular}

Table 2 .

Who do you consider yourself by nationality, $\%{ }^{6}$ ?

\begin{tabular}{|l|c|c|c|c|c|c|c|c|}
\hline & Ukraine & West & Center & South & East & Donbass & Ukrainians & Russians \\
\hline Ukrainian & 85.7 & 96.7 & 94.5 & 84.2 & 79.8 & 59.9 & 97.8 & 70.6 \\
\hline Russian & 11.0 & 2.4 & 3.0 & 12.1 & 15.9 & 33.4 & 1.8 & 24.0 \\
\hline Other nationality & 2.1 & 0.7 & 1.0 & 1.9 & 1.9 & 6.6 & 0.3 & 3.7 \\
\hline It's hard to answer & 1.2 & 0.2 & 1.5 & 1.9 & 2.4 & 0.0 & 0.2 & 1.7 \\
\hline
\end{tabular}

${ }^{4}$ Consolidation of Ukrainian society: ways, challenges, prospects: information and analytical materials for professional discussion December 16, 2016. Kyiv: Razumkov Center, 2016. 100 p.

5 Ibid. P. 20.

6 Ibid. P. 49. 
However, civil and national identities are inferior in the hierarchy of identities, if we take the self-identification of Ukrainian citizens by belonging to microgroups: related, professional, age, gender groups. This indicates a certain problem in the formation of national identity, which can manifest itself in the priority of personal and corporate interests based on Ukrainian national interests.

Nevertheless, there is clearly a certain positive dynamics in the formation of national identity in independent Ukraine. Thus, respondents consider Ukraine first of all as their homeland, and then the country in which they live and citizenship, which records only formal belonging to the Ukrainian state ${ }^{7}$. This positive dynamics can be traced primarily due to the rapid growth of national consciousness in central Ukraine, which is approaching the level of Western Ukraine.

Table 3 .

Which of the following do you primarily associate with the word «Ukraine» ${ }^{8}, \%$.

\begin{tabular}{|l|c|c|c|c|c|c|c|c|}
\hline & Ukraine & West & Center & South & East & Donbass & Ukrainians & Russians \\
\hline My homeland & 45.5 & 56.4 & 55.9 & 28.2 & 35.1 & 32.2 & 50.0 & 19.6 \\
\hline The country I live in & 23.9 & 18.7 & 18.1 & 33.8 & 26.2 & 34.1 & 21.5 & 38.4 \\
\hline $\begin{array}{l}\text { The state of which I } \\
\text { am a citizen }\end{array}$ & 17.0 & 11.4 & 14.2 & 22.2 & 25.4 & 17.4 & 16.2 & 22.8 \\
\hline $\begin{array}{l}\text { What surrounds me } \\
\text { in everyday life (my } \\
\text { city / town / village, } \\
\text { familiar landscapes, } \\
\text { r e l a t i ve s a n d } \\
\text { countrymen) }\end{array}$ & 10.9 & 8.7 & 9.7 & 9.5 & 8.5 & 9.1 & 8.5 \\
\hline Part of Europe & 1.2 & 2.1 & 0.9 & 2.3 & 0.5 & 0.6 & 1.2 & 1.3 \\
\hline Part of Russia & 1.2 & 0.0 & 0.7 & 0.5 & 1.4 & 4.7 & 0.8 & 4.9 \\
\hline
\end{tabular}

However, for residents of Eastern and Southern Ukraine, as well as the Donbas, Ukraine is mostly associated as the country in which they live, or the state of which they are citizens. This shift in emphasis shows that for residents of these regions, Ukraine has not yet acquired its significance as a homeland, which reflects the problematic formation of national identity in modern Ukrainian society. An even worse situation can be traced across the entire country on ethnic grounds: only half of ethnic Ukrainians consider Ukraine as their homeland (50.0\%), which indicates their Russification and still low level of national consciousness; and ethnic Russians practically do not consider Ukraine as their homeland $(19.6 \%)$, for them Ukraine is primarily the country in which they live $(38.4 \%)$, or the state of which they are citizens (22.8\%). Despite this, it should also be noted that there is a certain positive dynamics in the integration of Russians into modern Ukrainian society, since even they consider Ukraine an original and self-sufficient country, and not as part of Russia

\footnotetext{
7 Consolidation of Ukrainian society... P. 18.

8 Ibid.
} 
$(4.3 \%)$ or Europe (1.3\%). For ethnic Ukrainians, this trend is even more pronounced: only $1.2 \%$ consider Ukraine as part of Europe, and $0.8 \%$ as part of Russia.

An important component of a common national identity is patriotism. A sociological study revealed a significant increase in the level of patriotism among Ukrainian citizens despite regional differences: two-thirds of respondents consider themselves patriots of Ukraine, and three-quarters confirm the presence of feelings of patriotism and love for Ukraine 9 .

The results of the survey confirm the fact that Euromaidan, the revolution of dignity and the struggle for independence of Ukraine, the heroism and dedication of the Ukrainian military and volunteers shown in the fight against Russian aggression and separatist movements, the annexation of Crimea and parts of Donbass by Russia, the military actions in eastern Ukraine have increased the sense of patriotism in Ukraine ${ }^{10}$. However, according to the results of the survey, the authorities' miscalculations in implementing reforms in 2014-2016 weakened the sense of patriotism among a certain part of Ukrainian citizens ${ }^{11}$.

Despite dissatisfaction with the actions of the authorities, Ukrainian citizens are generally optimistic about the future of Ukraine as an independent state. Despite the difficult socio-economic situation in Ukraine, the majority of its citizens believe in the ability of their country to overcome existing problems and difficulties and in the presence of prospects for a decent life in it $^{12}$. However, the government's mistakes in the reform process and the fall in the standard of living of the people record moderate optimism about the prospects for improving their standard of living to a lesser extent for themselves, and to a greater extent for their children and grandchildren. The majority of respondents believe that in the future Ukraine will still be a highly developed, democratic, influential European country $(36.5 \%)$ or follow a special path of development $(21.4 \%)^{13}$. A «pessimistic» version of Ukraine's future is supported by a small part of respondents.

Ukraine will be able to achieve positive prospects based on the awareness of its population of the common historical fate. Ukrainians believe that Ukraine has its own history, and accordingly, $85 \%$ of respondents believe that Ukrainian children should cultivate a sense of love for Ukraine and respect for their history ${ }^{14}$. All this will make it easier for the younger generation of Ukrainians to achieve unity, solidarity and mutual help, according to the majority.

The Ukrainian language is one of the main markers of the formation of a common national identity of Ukraine. The majority of respondents believe that every citizen of Ukraine should speak the Ukrainian language to the extent sufficient for everyday communication and communicate it in official institutions. They agree with the need for state assistance in the development and dissemination of the Ukrainian language, based on the fact that the Ukrainian language has been subjected to harassment for a long time $(58.6 \%)^{15}$. At the

\footnotetext{
9 Consolidation of Ukrainian society... P. 21, 26.

${ }^{10}$ Ibid. P. 35.

${ }^{11}$ Ibid. P. 26.

${ }^{12}$ Ibid. P. 34.

${ }^{13}$ Ibid. P. 62.

${ }^{14}$ Ibid. P. 38.

${ }^{15}$ Ibid. P. 41.
} 
same time, the relative majority of respondents $(44.9 \%)$ do not support granting the state the right to restrict the use of other languages on its territory.

In general, Ukrainian citizens highly appreciate the possibility of meeting their cultural and religious needs in an independent Ukraine (89.66\% and 89.2\%). However, there is no consensus in Ukrainian society on whether to preserve the cultural characteristics of regional and ethnic groups or cultural unification, since the level of support for both these positions differs little ${ }^{16}$. There is also no clear advantage in the number of supporters in terms of state support only for the Ukrainian language and culture or support for the languages and cultures of other peoples living in Ukraine. However, Ukrainian citizens oppose the concept of a «melting pot», when different ethnic groups mix with the titular nation ${ }^{17}$. Respondents also record certain problems in the sphere of ensuring proper unity between different regions, the presence, first of all, of a certain isolation from each other as a problem of forming a common national identity for all citizens ${ }^{18}$. However, the relative majority of all Ukrainian citizens who are aware of the difference between them and residents of other regions mostly consider these differences to be a positive phenomenon.

Summing up, we will identify the main factors of consolidation and separation of modern Ukrainian society.

According to the citizens of Ukraine, the consolidation of Ukrainian society will be most facilitated by:

- overcoming existing socio-economic problems, improving the well-being of the majority of citizens ( $67 \%$ of respondents);

- overcoming corruption and bringing corrupt officials to justice $(66 \%)$;

- change of power in Ukraine, coming to power of honest, professional, uncorrupted people $(51 \%)$;

- a more equitable distribution of public goods, reducing the gap between the incomes of rich and poor citizens $(48 \%)$;

- increased participation of citizens in solving socially important problems at the state and regional levels» $(29 \%)^{19}$.

Factors of separation of the country, according to citizens, can be:

- attitude to the government and state policy (43\%);

- attitude to the war in the East (41\%);

- attitude to Russia (40\%);

- federalization of Ukraine (33\%);

- joining a defense alliance with Russia (32\%);

- course for NATO membership (31\%);

- refusal to return Crimea, consent to grant special status to the occupied territories of Donbass (31\%).

- vision of prospects and directions for the development of our country (30\%);

- attitude to Europe and the USA (28\%);

\footnotetext{
${ }^{16}$ Consolidation of Ukrainian society... P. 46.

${ }^{17}$ Ibid. P. 47, 49.

${ }^{18}$ Ibid. P. 64.

${ }^{19}$ Ibid. P. 66.
} 
- financial issues $(28 \%)^{20}$.

The sociological study highlights the basis around which integration and consolidation of Ukrainian citizens is possible.

Table 4.

What can be the basis for unity of residents of Ukraine, $\%{ }^{21}$ ?

\begin{tabular}{|l|c|c|c|c|c|c|c|c|}
\hline & Ukraine & West & Center & South & East & Donbass & Ukrainians & Russians \\
\hline $\begin{array}{l}\text { A common vision of } \\
\text { the future direction } \\
\text { of state development }\end{array}$ & 61.6 & 62.9 & 59.4 & 54.6 & 64.2 & 66.5 & 62.2 & 58.6 \\
\hline $\begin{array}{l}\text { Common problems } \\
\text { facing Ukrainian } \\
\text { citizens today }\end{array}$ & 58.7 & 54.8 & 57.8 & 64.4 & 68.5 & 50.9 & 59.5 & 54.1 \\
\hline $\begin{array}{l}\text { Common history and } \\
\text { common assessments } \\
\text { of events and figures } \\
\text { of the historical past }\end{array}$ & 43.2 & 37.6 & 48.9 & 38.6 & 51.5 & 31.5 & 44.1 & 37.4 \\
\hline $\begin{array}{l}\text { Common state } \\
\text { language }\end{array}$ & 22.3 & 29.8 & 24.9 & 11.6 & 21.3 & 14.6 & 24.2 & 9.5 \\
\hline Common enemy & 22.0 & 29.6 & 21.0 & 13.9 & 19.4 & 22.7 & 23.5 & 11.7 \\
\hline
\end{tabular}

However, the consolidation of the Ukrainian people is possible primarily on the basis of their own national idea. Thus, a sociological study has established that it is the Ukrainian national idea that can become the conceptual basis for consolidating modern Ukrainian society, as well as neutralizing the factors of separation of the country. In particular, four-fifths $(81 \%)$ of respondents believe that in order to consolidate society, each country should have its own common national idea for all citizens (and only $6 \%$ believe that it is not necessary $)^{22}$. The majority of respondents in each region agree that such an idea is necessary (from $67 \%$ in the South to $91 \%$ in the West of the country) ${ }^{23}$.

After the 2019 presidential and parliamentary elections, Ukraine was in a completely new political reality, which was also reflected in the processes of forming national identity in Ukraine. These new realias reflect the results of a sociological study on the attitude of Ukrainian regions to patriotism, language and foreign policy priorities, which was conducted by the Ilk Kucher foundation for Democratic initiatives together with the Razumkov Center's sociological service from December 13 to 18, 2019 in all regions of Ukraine with the exception of Crimea and the occupied territories of Donetsk and Luhansk regions ${ }^{24}$. They showed an increasing tendency to blur the existing division of Ukraine after Russian aggression, Russia's occupation of Crimea and parts of the Donetsk and Luhansk regions,

\footnotetext{
${ }^{20}$ Consolidation of Ukrainian society... P. 11.

${ }^{21}$ Ibid. P. 14-15.

22 Ibid. P. 34.

23 Ibid.

${ }^{24}$ Bekeshkina I. Patriotism, language and foreign policy priorities - public opinion of Ukraine. Democratic initiative. 2020. January 21. URL: https://dif.org.ua/article/\%20patriotyzm_mova\%20\%20.
} 
where pro-Russian orientations were most often traced. Russian aggression has become an important factor in the consolidation of Ukrainian society, and the signing and implementation of the association agreement between Ukraine and the EU make significant changes in the development of the state and the geopolitical orientations of its citizens. At the same time, a sociological study has revealed a tendency to a certain fragmentation of Ukraine. In Ukraine, there is a tendency to distinguish four regions (West, Center, South and East) with their own regional specifics. The dynamics of the national identity formation based on citizenship and the intensification of the processes of formation of the Ukrainian political nation by increasing the share of residents of the East and South of Ukraine who identify themselves primarily as citizens of Ukraine (West $-76.2 \%$, Center $-77.7 \%$, South $-83.6 \%$, East-65.7\%) is increasingly being traced ${ }^{25}$.

The vast majority of the population of Ukraine $(74.9 \%)$ considers themselves primarily as citizens of Ukraine. Significantly fewer citizens $(15.6 \%)$ chose regional identification as belonging to their region, district, city or village ${ }^{26}$. If we consider the dynamics of the formation of national identity in modern Ukrainian society for a longer time - 2013-2019, then there is clearly a positive tendency, when the number of respondents who identify themselves primarily as citizens of Ukraine increases. However, there are some fluctuations depending on events in Ukraine and abroad, which may affect the processes of national identity formation. Thus, after the outbreak of patriotism in 2014, and its peak in 2015-2016, in 2017 and 2018, there is a certain decline, which may be due to dissatisfaction with the state policy pursued by those pro-European political forces that came to power in Ukraine after the revolution of dignity. But, in 2019, the number of citizens who primarily consider themselves citizens of Ukraine will start to grow again. This year, presidential and parliamentary elections were held, which resulted in a change of power. Political optimism has increased among the population of Ukraine, and there were hopes for positive changes in Ukraine after the reset of power caused by the election of President of Ukraine V. Zelensky and for the first time in the history of Ukraine the formation of a parliamentary majority of the presidential party «Servant of the People».

Table 5.

Who do you consider yourself in the first place, $\%{ }^{27}$ ?

\begin{tabular}{|l|c|c|c|c|c|c|}
\hline & $\begin{array}{c}\text { December } \\
2013\end{array}$ & $\begin{array}{c}\text { December } \\
2014\end{array}$ & $\begin{array}{c}\text { December } \\
2015\end{array}$ & $\begin{array}{c}\text { December } \\
2017\end{array}$ & $\begin{array}{c}\text { December } \\
2018\end{array}$ & $\begin{array}{c}\text { December } \\
2019\end{array}$ \\
\hline $\begin{array}{l}\text { A resident of the region } \\
\text { where you live }\end{array}$ & 35.3 & 19.2 & 12.2 & 15.8 & 18.2 & 15.6 \\
\hline A citizen of Ukraine & 54.2 & 73.2 & 80.9 & 72.9 & 67.5 & 74.9 \\
\hline $\begin{array}{l}\text { A representative of your } \\
\text { own ethnic group, Nation }\end{array}$ & 2.0 & 1.3 & 2.4 & 2.8 & 3.2 & 2.6 \\
\hline A citizen of Russia & 3.2 & 0.1 & 0.3 & 0.3 & 0.0 & 0.3 \\
\hline $\begin{array}{l}\text { A citizen of the former } \\
\text { USSR }\end{array}$ & 2.5 & 2.9 & 1.9 & 2.9 & 2.2 & 2.7 \\
\hline
\end{tabular}

\footnotetext{
${ }^{25}$ Bekeshkina I. Patriotism, language and foreign policy priorities.

${ }^{26}$ Ibid.

${ }^{27}$ Ibid.
} 


\begin{tabular}{|l|c|c|c|c|c|c|}
\hline A citizen of Europe & 2.3 & 0.9 & 0.6 & 1.3 & 2.0 & 1.2 \\
\hline A citizen of the world & 0.1 & 1.9 & 1.2 & 0.8 & 0.9 & 1.5 \\
\hline Other & 0.3 & 0.6 & 0.2 & 0.2 & 1.0 & 0.1 \\
\hline It's hard to say & 0.1 & 0 & 0.3 & 2.9 & 5.0 & 1.0 \\
\hline
\end{tabular}

This sociological study showed an increase in the level of patriotism. Ukrainians thus identified the main components of patriotism: love for their country $(80 \%)$, readiness to defend their country, if necessary - with weapons (64\%), education of love and respect for their country among children (58\%), compliance with all the laws of the country $(56 \%)$, knowledge of the history of their country, its culture $(51 \%)^{28}$.

Ukraine is approaching the necessary consensus on the issue that the Ukrainian language is an important attribute of Ukraine's independence ( $81 \%$ of citizens agree, $55 \%$ of them - «absolutely» and another 26\% - «rather, yes») in all regions of Ukraine: Western (95\%), Central (86\%), Southern (71\%), Eastern $(64 \%)^{29}$. The absolute majority of Ukrainians agree that all state leaders and civil servants should communicate in the state language during working hours $(80 \%$ of respondents agree, $56 \%$ of them definitely agree and $24 \%$ rather agree) in all regions of the Ukrainian state: Western (96\%), Central (86\%), Southern (71\%), Eastern (64\%). The majority of citizens also believe that at least half of the content in the Ukrainian media should be in Ukrainian (79\% of respondents agree, of which 53\% agree with this unconditionally, and 26\% - rather, yes) in all regions: Western $(96 \%)$, Central (82\%), Eastern (66\%), Southern $(63 \%)^{30}$.

There is no such unanimity on the status of the Russian language. In Ukraine, the majority of Ukrainians believe that Russian should be freely used in private life, but Ukrainian remains the only state language $(69 \%)^{31}$. However, in the Eastern region, although support for Russian as the language of communication in everyday life prevails, the people recognize Ukrainian as the state language (42.4\%), although $24 \%$ advocate the possibility of Russian as the official language in the regions, and $31 \%$ support giving Russian the status second state language ${ }^{32}$.

A sociological survey in 2019 found that the people of Ukraine in general have distinguished themselves with their foreign policy orientations and the direction of international integration, and are approaching a consensus on this issue ${ }^{33}$. There has been a positive trend in the growth of supporters of European integration in Ukraine over the past five years. The turning point was the year 2014, when Russia unleashed a «hybrid war» against Ukraine, annexed Crimea and part of the Donbas, and supports the military conflict in eastern Ukraine. This led to a sharp decrease in the number of supporters of joining the Eurasian Economic Union. If in 2013 there were a small majority of supporters of joining the EU (46\%) compared to supporters of joining the Eurasian Economic Union (36\%), then in 2019 their ratio changed sharply in favor of the European Union (64\%), against joining

\footnotetext{
${ }^{28}$ Bekeshkina I. Patriotism, language and foreign policy priorities.

${ }^{29}$ Ibid.

${ }^{30} \mathrm{Ibid}$.

${ }^{31}$ Ibid.

${ }^{32}$ Ibid.

${ }^{33}$ Ibid.
} 
the Eurasian Economic Union (13\%). However, we should also note the threatening trend of a slight but gradual increase in the number of respondents who support Ukraine's accession to the Eurasian Economic Union even despite Russian aggression since 2018 (in $2017-10.8 \%$, in $2018-12.5 \%$, in $2019-12.7$ ). If Ukraine fails to overcome the systemic crisis and the standard of living continues to decline, the number of supporters of integration into the Eurasian Union may grow.

Table 6.

What integration direction should Ukraine follow, $\%{ }^{34}$ ?

\begin{tabular}{|l|c|c|c|c|c|c|}
\hline & $\begin{array}{c}\text { December } \\
2013\end{array}$ & $\begin{array}{c}\text { December } \\
2014\end{array}$ & $\begin{array}{c}\text { December } \\
2016\end{array}$ & $\begin{array}{c}\text { December } \\
2017\end{array}$ & $\begin{array}{c}\text { December } \\
2018\end{array}$ & $\begin{array}{c}\text { December } \\
2019\end{array}$ \\
\hline Joining the EU & 46.4 & 57.3 & 57.9 & 59.1 & 59.4 & 64.2 \\
\hline $\begin{array}{l}\text { Joining the Eurasian Economic } \\
\text { Union }\end{array}$ & 35.7 & 16.3 & 11.0 & 10.8 & 12.5 & 12.7 \\
\hline It's hard to answer & 17.8 & 26.5 & 31.1 & 30.2 & 28.1 & 23.1 \\
\hline
\end{tabular}

It should also be noted the positive dynamics of the increase in the number of supporters of Euro-Atlantic integration and Ukraine's accession to NATO over the past eight years. According to the results of the research, before the Russian aggression in 2014, supporters of the neutral status of Ukraine prevailed in Ukraine. In 2014, there was a turning point when the number of people who supports joining NATO became higher than supporters of the neutral status of Ukraine. Further, there was a positive trend in the increase in the number of supporters of Euro-Atlantic integration, and in 2019, for the first time, the majority of respondents supported Ukraine's accession to NATO.

Table 7.

What do you think is the best security option for Ukraine $\%{ }^{35}$ ?

\begin{tabular}{|l|c|c|c|c|c|c|c|c|}
\hline & $\begin{array}{c}\text { April } \\
2012\end{array}$ & $\begin{array}{c}\text { May } \\
2014\end{array}$ & $\begin{array}{c}\text { December } \\
2014\end{array}$ & $\begin{array}{c}\text { November } \\
2015\end{array}$ & $\begin{array}{c}\text { December } \\
2016\end{array}$ & $\begin{array}{c}\text { December } \\
2017\end{array}$ & $\begin{array}{c}\text { December } \\
2018\end{array}$ & $\begin{array}{c}\text { December } \\
2019\end{array}$ \\
\hline $\begin{array}{l}\text { Joining } \\
\text { NATO }\end{array}$ & 13.0 & 32.6 & 46.4 & 45.7 & 44.1 & 38.5 & 46.1 & 51.2 \\
\hline $\begin{array}{l}\text { Military } \\
\text { alliance with } \\
\text { Russia }\end{array}$ & 26.2 & 13.6 & 10.1 & 8.2 & 6.4 & 5.3 & 7.2 & 5.5 \\
\hline $\begin{array}{l}\text { Military } \\
\text { alliance with } \\
\text { the United } \\
\text { States }\end{array}$ & - & 1.5 & - & 3.4 & 3.9 & 5.0 & 2.9 & 1.5 \\
\hline $\begin{array}{l}\text { Non-aligned } \\
\text { status of } \\
\text { Ukraine }\end{array}$ & 42.1 & 28.3 & 20.9 & 22.6 & 26.4 & 28.6 & 24.1 & 26.1 \\
\hline Other & 0.9 & 1.0 & 1.0 & 2.4 & 2.5 & 3.1 & 3.0 & 1.6 \\
\hline $\begin{array}{l}\text { It's hard to } \\
\text { answer }\end{array}$ & 17.8 & 23.7 & 21.7 & 17.6 & 16.6 & 19.5 & 16.7 & 14.1 \\
\hline
\end{tabular}

\footnotetext{
${ }^{34}$ Ibid.

${ }^{35}$ Ibid.
} 
It is worth noting that respondents generally gave a negative assessment of the reform activities of the political forces that came to power after Euromaidan and the revolution of dignity in 2014, which did not meet their expectations ${ }^{36}$. This is primarily due to the fact that the reforms, according to respondents, carried out by the authorities in recent years, did not meet the interests of the majority of Ukrainian citizens $(67 \%)^{37}$. Therefore, these political forces suffered a crushing defeat in the 2019 presidential and parliamentary elections. New political forces came to power, which were mostly not engaged in politics before, and did not have the proper experience of political activity and public administration practice.

The new President of Ukraine V. Zelensky and his political party «Servant of the People», who came to power in 2019, pursued a policy that also did not meet popular expectations. . Therefore, in a sociological study conducted by the Razumkov Center in February and October-November 2020, the majority of respondents express distrust of all national-level politicians whose name was represented in the questionnaire, including the president of Ukraine V. Zelensky, who was trusted by $33 \%$, and distrust by $62 \%$ of respondents ${ }^{38}$.

Also observed in 2020 the rapid decline of trust in government and public institutions. Respondents most often express distrust in the state apparatus (officials) (79\%), the Verkhovna Rada of Ukraine (76\%), courts and the judiciary $(75 \%)$, the Government of Ukraine (75\%), political parties (73\%), and commercial banks (73\%). ), The National Anti-Corruption Bureau of Ukraine (NABU) (72.5\%), the National Agency for the Prevention of Corruption (NAPC) (71\%), the Specialized Anti-Corruption Prosecutor's Office (70\%), the Supreme Anti-Corruption Court (70\%), the Prosecutor's Office (70\%). ), The Constitutional Court of Ukraine (65\%), the National Bank of Ukraine (64\%), local courts (63\%), the Supreme Court $(63 \%)$, trade unions $(54 \%)$, the national police $(53 \%)$, the Security Service of Ukraine $(51 \%)^{39}$.

Among state and public institutions, only the Armed Forces of Ukraine (66\%), The Church (62\%), the State Emergency Service (60\%), volunteer organizations $(60 \%)$, the state border service $(55 \%)$, the heads of cities (towns, villages) where the respondent lives $(54 \%)$, the National Guard of Ukraine (52\%), volunteer battalions $(52 \%)$, as well as the councils of the city (town, village) where the respondent lives $(50 \%)$ remain trusted $^{40}$.

Assessing the situation in Ukraine in October-November 2020, the majority of respondents note that our country is moving in the wrong direction $(65.5 \%)$, and only $17.5 \%$ believe that events in it are developing correctly ${ }^{41}$. They believe that the President of Ukraine V. Zelensky did not fulfill the following promises: removing oligarchs from influencing politics (71.5\%), creating new jobs (70\%), establishing peace in eastern Ukraine (63\%), fighting corruption $(62 \%)$, introduction of real democracy $(62 \%)$, reduction of utility tariffs $(56 \%)$, de-

\footnotetext{
${ }^{36}$ Consolidation of Ukrainian society: ways, challenges, prospects...P. 29.

${ }^{37}$ Ibid. P. 30.

${ }^{38}$ Citizens' assessment of the situation in the country, the level of trust in social institutions and politicians, electoral orientations of citizens (October-November 2020). Razumkov Center. 2020.10 sheet. URL: https://razumkov.org.ua/napriamky/sotsiologichni-doslidzhennia/otsinka-gromadianamy-sytuatsii-v-kraini-riven-doviry-do-sotsialnykh-instytutiv-ta-politykiv-elektoralni-oriientatsii-gromadianzhovten-lystopad-2020r.

${ }^{39}$ Ibid.

${ }^{40}$ Ibid.

${ }^{41}$ Ibid.
} 
shadowing of the economy, money laundering (54\%), increase of pensions (53\%), provision of hospitals and schools with financing and modern equipment $(50 \%)$, increase of salaries of teachers and doctors (47\%), prevention of business infringement by militiamen $(46 \%)^{42}$.

Therefore, in the local and regional elections, the President of Ukraine and his «Servant of the People» party failed to develop their success at the national level, and in fact were defeated compared to the results of the 2019 parliamentary elections. The greatest concern is that the «Opposition Platform For Life» party has been able to gain a foothold at all levels in south-eastern Ukraine, winning in Odesa, Mykolaiv, Zaporizhia, Donetsk, Luhansk and Kherson regions ${ }^{43}$. And took the second place in Kharkiv, Dnipropetrovsk and Sumy regions. The «Opposition Platform For Life» (OPZZh) is the bearer of Russian identity. All this today poses a real threat to the independence and territorial integrity of Ukraine, the spread of separatism in the southern and eastern regions of the state, the strengthening of the confrontation between the center and the regions, the East and West of Ukraine, and the destabilization of the political situation in the state.

Sociological studies of 2020 and the results of the 2020 Local Government elections in Ukraine showed an increase in the fragmentation of Ukrainian society, the dispersion and mutual struggle of pro-Ukrainian forces, as well as the strengthening of the positions of pro-Russian forces in the South and East of Ukraine, which pose a threat to the national unity and security of the Ukrainian state in the conditions of Russian aggression. Therefore, in order to implement the Ukrainian national idea, consolidate the people and successfully complete the nation-building process in Ukraine, it is necessary to form a Platform of National Unity of Ukraine, around which all progressive pro-Ukrainian forces could unite, and initiate activities of nationwide Permanent Roundtable.

After the declaration of independence, a single national identity has not yet been formed in the Ukrainian state. In Ukraine, first of all, there were two large subregions - «Right Bank» and «Left Bank», which in matters of cultural, economic, party-political and foreign policy spheres took opposite positions. In these subregions, two poles are particularly clearly distinguished - Galicia and Donbass. Galicia, under its national identity, considers itself primarily as Ukrainian ethnic and political community, and Donbass, as a community that unites on the basis of citizenship. The West of Ukraine tends to Western Europe, and the East of Ukraine tends to Russia.

The stay of Ukrainian lands in their independent state for a quarter of a century, the Orange Revolution, the Revolution of Dignity and Ukraine's struggle for independence against Russian aggression had a positive effect on the formation of national identity in the greater territory of Ukraine.

During this period, civil and national identity has become a priority for Ukrainian citizens in relation to regional, class, religious and political group identities. The number of Ukrainians who consider Ukraine first of all as their homeland, and then the country in which they live and citizenship, which fixes the formal affiliation to the Ukrainian state, is growing. There was a significant increase in the level of patriotism among Ukrainian

\footnotetext{
${ }^{42}$ Citizens' assessment of the first year of activity of the president and the new government (April 2020. sociology). Razumkov Center. 2020. June 26. URL: https://razumkov.org.ua/napriamky/sotsiologichnidoslidzhennia/otsinka-gromadianamy-pershogo-roku-diialnosti-prezydenta-ta-novoi-vlady-kviten-2020r.

${ }^{43}$ Elected deputies of local councils. Central Election Commission. URL: https://www.cvk.gov.ua/pls/ vm2020/pvm002pt001f01 $=695$ pt00_t001 f01 $=695 . h t m l$.
} 
citizens, despite the existing regional differences. Regardless the difficult socio-economic situation in Ukraine, the majority of its citizens believe that in the future Ukraine will still be a highly developed, democratic, influential European country or follow a special path of development. The vast majority of respondents believe that Ukrainian children should develop a sense of love for Ukraine and respect for their history. Ukraine is approaching the necessary consensus on the issue that the Ukrainian language is an important attribute of Ukraine's independence in all its regions. Almost two-thirds of respondents believe that joining the EU is the main integration direction of Ukraine, and only a certain part supports its entry into the Eurasian Union today. In Ukraine, the share of supporters of joining NATO is also gradually growing, and today more than half of the population considers this the best option for ensuring security for the Ukrainian state.

Along with the positive dynamics, Ukrainian citizens also highlighted problematic factors in the formation of national identity in modern Ukrainian society during sociological surveys. There is no consensus in Ukrainian society on whether to preserve the cultural characteristics of regional and ethnic groups or implement cultural unification. Respondents today record a certain isolation of regions from each other, which today remains one of the main problems of ensuring national unity and forming a common national identity for all citizens. The main factors that can divide Ukraine today are specified: attitude to the authorities and state policy; attitude to the war in the East; attitude to Russia; attitude to Europe and the United States; federalization of Ukraine; joining the defense alliance with Russia; the course for NATO membership; refusal to return Crimea, consent to grant special status to the occupied territories of Donbass; vision of prospects, directions of development of their country; financial issues.

Sociological research highlights the basis around which integration and consolidation of Ukrainian citizens is possible: a common vision of the future direction of State Development; solving common problems facing Ukrainian citizens today; a common history and joint assessments of events and figures of the historical past; a common state language; an idea of a common enemy, strategic allies and opponents of Ukraine. Citizens of Ukraine believe that the consolidation of Ukrainian society will most contribute to: overcoming existing socio-economic problems, improving the well-being of the majority of citizens; overcoming corruption and bringing corrupt officials to justice; changing the government in Ukraine, coming to power honest, professional, uncorrupted people; a fairer distribution of public goods, reducing the gap between the incomes of rich and poor citizens; increasing the participation of citizens in solving socially important problems at the state and regional levels. According to the respondents, it is the Ukrainian national idea that can become the conceptual basis for consolidating modern Ukrainian society.

Sociological studies of 2020 and the results of local government elections in 2020 in Ukraine showed an increase in the fragmentation of Ukrainian society, which is accompanied by the spraying and mutual struggle of pro-Ukrainian forces, as well as the strengthening of the positions of pro-Russian forces in the South and East of Ukraine, which pose a threat to the national unity and security of the Ukrainian state in the conditions of Russian aggression.

In order to implement the Ukrainian national idea, consolidate the people and successfully complete the nation-building process in Ukraine, it is necessary to form a Platform of National Unity of Ukraine, around which all progressive pro-Ukrainian forces could unite, and initiate activities of nationwide Permanent Roundtable. 


\section{REFERENCES}

1. Bekeshkina, I. (2020, January 21). Patriotism, language and foreign policy priorities public opinion of Ukraine. Democratic initiative. Retrieved from https://dif.org.ua/ article/\%20patriotyzm_mova\%20\%20 [in English].

2. Beletskiy, M. I., \& Topygo, A. K. (1998). National-cultural and ideological orientations of Ukraine. According to sociological polls. Policy, 4, 74-89 [in English].

3. Citizens' assessment of the first year of activity of the president and the new government (April 2020. sociology). (2020, June 26). Razumkov Center. Retrieved from https:// razumkov.org.ua/napriamky/sotsiologichni-doslidzhennia/otsinka-gromadianamypershogo-roku-diialnosti-prezydenta-ta-novoi-vlady-kviten-2020r [in English].

4. Citizens' assessment of the situation in the country, the level of trust in social institutions and politicians, electoral orientations of citizens (October-November 2020). (2020). Razumkov Center. Retrieved from https://razumkov.org.ua/napriamky/sotsiologichnidoslidzhennia/otsinka-gromadianamy-sytuatsii-v-kraini-riven-doviry-do-sotsialnykhinstytutiv-ta-politykiv-elektoralni-oriientatsii-gromadian-zhovten-lystopad-2020r [in English].

5. Consolidation of Ukrainian society: ways, challenges, prospects: information and analytical materials for professional discussion December 16, 2016. (2016). Kyiv: Razumkov Center [in English].

6. Elected deputies of local councils. Central Election Commission. Retrieved from https://www.cvk.gov.ua/pls/vm2020/pvm002pt001f01=695pt00_t001f01=695.html [in English].

7. Pasichnyk, V. (1997). National security in the context of Ukrainian-Russian relations. Lviv: Stavropigon [in English].

8. Results of the cross-regional sociological survey «the state of Ukrainian society on the eve of the 1998-199 elections» conducted by the Genesa Political Science Center under the leadership of Viktor Nebozhenko in May 1997. (1997). Lviv: Stavropigon [in English]. 
Орест КРАСІВСБКИЙ

доктор історичних наук, професор завідувач кафедри європейської інтеграції та права Львівського регіонального інституту державного управління Начіональної академії державного управління при Президентові України ORCID: https://orcid.org/0000-0002-7028-6038 e-mail:krasivski@ukr.net

Василь ПАСІЧНИК
доктор наук з державного управління, дочент кафедри європейської інтеграції та права Львівського регіонального інституту державного управління Національної академії державного управління при Президентові Украӥни ORCID: https://orcid.org/0000-0002-2447-2374 e-mail: v_pasychnyk@point.lviv.ua

\section{ДИНАМІКА ФОРМУВАННЯ НАЦІОНАЛЬНОЇ ІДЕНТИЧНОСТІ В НЕЗАЛЕЖНІЙ УКРАЇНІ}

Досліджено динаміку формування національної ідентичності в незалежній Україні. На основі аналізу результатів соціологічних досліджень розкрито стан, проблеми та перспективи формування української національної ідентичності. 3'ясовано, що на момент проголошення незалежності для України була характерна розмита національна ідентичність, де переважали саме регіональні ідентичності, коли Захід України орієнтувався на Європейський Союз, а її Схід та Південь - на Росію. За результатами соціологічних досліджень виявлено позитивну динаміку у формуванні української національної ідентичності в умовах незалежної України, оскільки саме громадянська ідентичність набула для громадян України пріоритетного значення щодо інших групових ідентичностей. Заразом доведено недоліки ліберального підходу щодо формування національної ідентичності, який робить акцент на забезпеченні прав людини, ігноруючи проблеми розмитості української національної ідентичності, незавершеність процесів націотворення в Україні та колективні права українців як титульної нації. Звернуто увагу на поглиблення розколів та фрагментацію українського суспільства, чим скористалася Росія, розв'язавши проти України «гібридну війну», анексувавши Крим та частину Донбасу. Простежено, що згідно 3 результатами останніх соціологічних досліджень сучасна політична еліта продовжує ігнорувати українські національні інтереси та очікування власного народу. Обгрунтовано пріоритетність саме національної інтеграції та забезпечення національної єдності України за збереження першочерговості європейської інтеграції поряд з іншими напрямками зовнішньополітичної орієнтації. Доведено, що концептуальною основою консолідації народу України може стати передусім українська національна ідея.

Ключові слова: національна ідентичність, Україна, консолідація суспільства, українська національна ідея. 


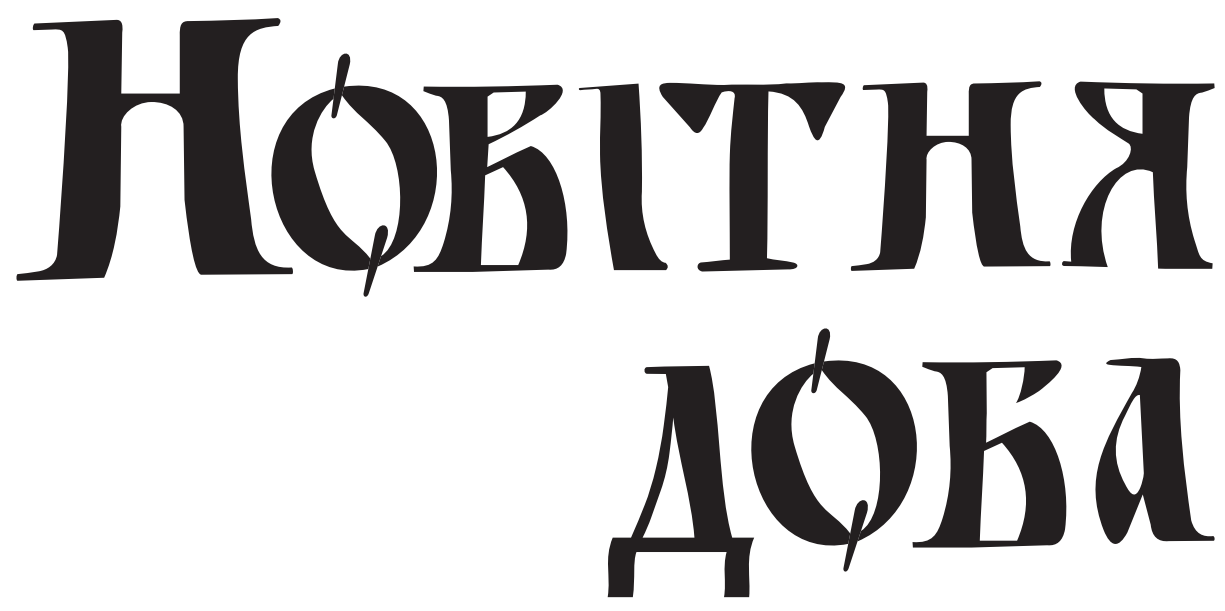

\section{випУСК 8}




Новітня доба / гол. ред. Михайло Романюк; НАН України, Інститут українознавства ім. І. Крип'якевича. Львів, 2020. Вип. 8. 256 с.

У збірнику представлено дослідження з новітньої української та світової історії за період від Першої світової війни і до сьогодення. Наголошено на закономірностях й особливостях розвитку суспільно-політичних і націєтворчих процесів в Україні у контексті історії європейських народів, зокрема становища українського суспільства в умовах тоталітарних режимів. Розкрито особливості українського визвольного руху, воєнної історії, формування державних інституцій, роль культури у становленні громадянського суспільства, вивчення джерел та історичної біографістики.

Contemporary era / resp. ed. Mykhailo Romaniuk; I. Krypiakevych Institute of Ukrainian Studies NAS of Ukraine. Lviv, 2020. Issue 8. 256 p.

The collection presents studies on modern Ukrainian and world history from the First World War to the present. Emphasis is placed on the regularities and features of the development of socio-political and nation-building processes in Ukraine in the context of the European nations' history, in particular the position of Ukrainian society under totalitarian regimes. The features of the Ukrainian liberation movement, military history, formation of state institutions, the role of culture in the development of civil society, the study of sources and historical biography are revealed.

Рекомендувала до друку вчена рада

Інституту українознавства ім. І. Крип'якевича НАН України

(протокол № 9 від 3.12.2020р.)

\section{ГОЛОВНИЙ РЕДАКТОР}

Романюк Михайло Васильович, к.і.н. (Україна)

\section{РЕДАКЦІЙНА КОЛЕГІЯ:}

Голембійовська-Тобіаш Анета (Gołębiowska-Tobiasz Aneta), dr (Польща)

Дзсньковський Томаш (Dzieńkowski Tomasz), dr (Польща)

Красівський Орест Якубович, д.і.н., проф. (Україна)

Муравський Олег Іванович, к.і.н., с.н.с. (Україна)

Пасіцька Оксана Ігорівна, к.і.н. (Україна)

Патер Іван Григорович, д.і.н., проф. (Україна)

Руда Оксана Василівна, к.і.н. (Україна)

Сова Андрій Олегович, к.і.н., доц. (Україна)

Соляр Ігор Ярославович, д.і.н., с.н.с. (Україна)

Стасюк Олександра Йосипівна, к.і.н., с.н.с. (Україна)

Трофимович Лілія Володимирівна, к.і.н., доц. (Украӥна)

Харук Андрій Іванович, д.і.н., проф. (Україна)

Цецик Ярослав Петрович, к.і.н., доц. (Украӥна) 


\section{MICT}

\section{АКТУАЛЬНІ ПРОБЛЕМИ НОВІТНЬОЇ ІСТОРІЇ}

РУДА Оксана. Освітнє питання в діяльності єврейських парламентарів у Законодавчому сеймі Польської держави (1919-1922) . . . . . . . . . . . 3

ПАСІЦЬКА Оксана. «Свій до свого по своє»: сільськогосподарські виставково-ярмаркові заходи в Галичині у 20-30-х роках ХХ століття . . . . 19

СЕНИЦЬКИЙ Віктор. Воєнна округа УПА «Говерля» в період німецької окупації (1943-1944) . . . . . . . . . . . . . . . . 28

ЛУНЬО Євген. Народно-оповідна традиція про знищення польської колонії Пишівка весною 1944 року . . . . . . . . . . . . . . . . . . . . . . 46

STASIUK Oleksandra. The nomination of candidates for deputies as a ritual element of soviet ostensible democracy $\ldots \ldots \ldots \ldots \ldots \ldots \ldots 77$

ЛУЦЬКИЙ Олександр. Двадцятип'ятитомне видання творів Івана Франка: львівський внесок. . . . . . . . . . . . . . . . . . . . . . . 88

ПОПКО Сергій. Участь військовослужбовців Збройних сил України в міжнародних операціях з підтримання миру і безпеки (1992-2018) . . . . 122

KRASIVSKYI Orest, PASICHNYK Vasyl. Dynamics of national identity formation in independent Ukraine . . . . . . . . . . 134

\section{ПОСТАTI}

ПАТЕР Іван. Іван Крип'якевич і наддніпрянська політична еміграція:

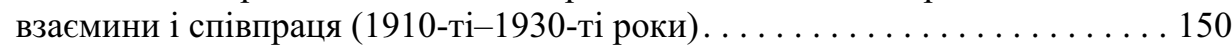

ПОСІВНИЧ Микола. Міжнаціональні стосунки в публіцистиці Степана Бандери. . . . . . . . . . . . . . . . . 178

\section{ПУБЛІКАЦІЯ ДОКУМЕНТІВ}

СОВА Андрій. Іван Боберський і Листопадові події у Львові 1918 року . . . . . 185 ЗАЙЦЕВ Юрій. Шістдесятництво у контексті українського опозиційного руху $1960-1980$-х років. . . . . . . . . 212 


\section{ОГЛЯДИ ТА РЕЦЕНЗЇ̈}

РОМАНЮК Михайло. [Рец.]: Збірник джерел до біографії Романа Шухевича у міжвоєнний період. [на]: Роман Шухевич у громадсько-політичному житті Західної України 1920-1939 рр.: спогади, документи, світлини / упоряд. і відп. ред. Андрій Сова; Центр незалежних історичних студій. Львів: Апріорі, 2019. 816 с. ................................ 239

АРТИМИШИН Юлія. [Рец.]: «(Не)чорно-біла історія українсько-польського діалогу пам'яті». [на]: Стрільчук Л., Нінічук А. Війна пам'яті та війни пам'ятників у сучасних українсько-польських відносинах. Луцьк: Вежа-Друк, 2019. 368 с. . . . . . . . . . . . . . . . . . . . . . . . . 246 